\title{
SeEDling SURVIVAL AND GROWTH OF TREE SPECIES: SITE CONDITION AND SEASONALITY IN TROPICAL DRY FOREST RESTORATION
}

\author{
Claudia Alvarez-Aquino ${ }^{1}$ y Guadalupe Williams-Linera ${ }^{2}$ \\ 'Instituto de Investigaciones Forestales; Universidad Veracruzana, Xalapa, Veracruz, México. \\ ${ }^{2}$ Instituto de Ecología, A.C, Xalapa, Veracruz, México
}

\begin{abstract}
Restoring seasonally dry tropical forest is a worldwide priority, since it is the most threatened of all major tropical forest types. In Veracruz, Mexico, the dry forest has been reduced to fragments and fallows representing $7 \%$ of the original cover. Our objective was to determine the effect of site condition and seasonality on seedling survival and relative growth rate in height and diameter of selected native tree species. We studied plant performance during two dry and two rainy seasons and the effect of existent woody vegetation $>1 \mathrm{~m}$ height. A total of 960 seedlings were transplanted: 40 individuals of six species (Cedrela odorata, Ceiba aesculifolia, Guazuma ulmifolia, Ipomoea wolcottiana, Luehea candida, Tabebuia rosea) in four fallows. Seedling survival and relative growth rate were monitored every four months during two years. Survival was higher in sites with more woody species richness, whereas relative growth rate in height was positively correlated with existent vegetation height. Relative growth rate was higher for all species and sites during the rainy season. In the site with less existent woody vegetation, seedling performance was poor and only Guazuma survived. Overall, Ceiba showed the highest survival rate (82-90\%) and the lowest relative growth rate. Guazuma had a high survival (20-94\%) and the highest relative growth rate; Cedrela showed the lowest survival (3-7\%) and high relative growth rate. Our results suggest that site condition, seasonality, and tree species selection act together on seedling performance during early establishment. A vital implication in terms of ecological restoration is the importance of taking advantage of existent vegetation even if it is scarce.
\end{abstract}

Keywords: dry season, nurse vegetation, rainy season, seedling performance, succession.

Resumen: La restauración del bosque tropical seco es prioritaria por ser el bosque más amenazado. En Veracruz, el bosque seco se ha reducido al 7\% de su cobertura original. Nuestro objetivo fue determinar el efecto de la condición del sitio a restaurar y la estacionalidad en la supervivencia y tasa de crecimiento relativo en altura y diámetro de especies de árboles nativos. Estudiamos el desempeño de plántulas durante dos estaciones secas y dos lluviosas, y el efecto de la vegetación leñosa existente $>1 \mathrm{~m}$ de altura. Se trasplantaron 960 plantas: 40 individuos de seis especie (Cedrela odorata, Ceiba aesculifolia, Guazuma ulmifolia, Ipomoea wolcottiana, Luehea candida, Tabebuia rosea) en cuatro sitios abandonados. La supervivencia y la tasa de crecimiento relativo se registraron cada cuatro meses durante dos años. La mayor supervivencia se observó en sitios con mayor riqueza de especies arbóreas y la tasa de crecimiento relativo en altura estuvo positivamente correlacionada con la altura de la vegetación existente. La mayor tasa de crecimiento relativo para especies y sitios se registró durante la estación lluviosa. En el sitio con menos vegetación, el desempeño de las plántulas fue pobre y sólo Guazuma sobrevivió. Ceiba mostró la mayor supervivencia (82-90\%) pero una tasa de crecimiento relativo baja; Guazuma presentó una supervivencia elevada (20-94\%) y la mayor tasa de crecimiento relativo; Cedrela mostró la menor supervivencia (3-7\%) y tasa de crecimiento relativo alta. Los resultados sugieren que la vegetación del sitio, la estacionalidad y las especies afectan el desempeño de las plántulas durante el establecimiento temprano. La implicación en términos de la restauración ecológica es la importancia de aprovechar la vegetación existente aunque ésta sea escasa.

Palabras clave: desempeño de plantas, estación de lluvia, estación de sequía, sucesión, vegetación nodriza.

$\mathbf{R}_{\mathrm{p}}^{\mathrm{e}}$ estoring tropical forests in dry habitats is a worldwide priority because tropical dry forests are the most threatened of all major tropical forest types (Janzen, 1988; Dirzo et al., 2011; Newton and Tejedor, 2011). Seasonally dry tropical forests (SDTF) have been subjected to unsustainable land use practices, including expansion of rangeland for livestock, overharvesting particularly for firewood, conversion to agriculture, and the rapid growth of urban settlements (Newton and Tejedor, 2011). Deforested and highly disturbed sites are a major challenge to consider for ecological restoration. In SDTF, some regeneration barriers--such as seed predation, lack of seed sources, plant herbivory, 
and difficult microclimatic conditions--are similar to those in moister tropical forests. However, there are other factors to take into account when implementing SDTF ecological restoration, such as much longer period of hydric stress and a soil seed bank practically without tree species seeds (Janzen, 1988; Rico-Gray and García-Franco, 1992; Ceccon et al., 2006; Vieira and Scariot, 2006; Griscom et al., 2009; Williams-Linera et al., 2011a).

First, when degradation is not excessive and some forest re-growth and nuclear trees are already present, passive restoration or encouragement of natural regeneration is recommended (Janzen, 1988; Lamb and Gilmour, 2003; Vieira and Scariot, 2006; Holl and Aide, 2011). The method consists of protecting the site from further sources of disturbance, such as cattle and fire, and allowing the successional process to occur (Griscom et al., 2009; Powers et al., 2009). The evidence suggests that fallows have the potential to recover SDTF (Janzen, 1988; Sampaio et al., 2007; WilliamsLinera et al., 2011b).

Second, when natural regeneration is not viable because of the degradation of deforested areas, intervention is necessary in order to initiate or accelerate the successional process. Some methods include seedling and planting nurserygrowing seedlings (Gerhardt and Hytterborn, 1992; Lamb and Gilmour, 2003; Vieira and Scariot, 2006; Sampaio et al., 2007; Griscom et al., 2009).

A third consideration is that species selection should be based on species attributes such as successional status, fire and drought resistance, and sprouting ability (Gerhardt and Hytterborn, 1992; Elliott et al., 2002; Vieira and Scariot, 2006). The use of native tree species is required to accelerate dry forest regeneration. While most dry forest tree species are easy to germinate and result in seedlings, their use is limited due to a lack of basic information about propagation and field performance (Vieira et al., 2008; Suárez-Islas, 2011).

The design of a restoration effort needs to take a fourth factor into consideration: site condition, especially in terms of vegetation. Although several studies have asserted that nurse plants are important in restoration, the effect of existent vegetation remains poorly understood. Restoration success and an increase in seedling survival depend upon the density of the remnant vegetation as well as the use of shrubs and nurse-plants (Aerts et al., 2007; Davidar et al., 2007, Santiago-García et al., 2008). Woody plants may have a facilitation effect on the early stages of tree forest seedling establishment, since shade can diminish seedling desiccation, however shade may decrease seedling survival by reducing light levels (Holl, 2002; Vieira and Scariot, 2006; Vieira et al., 2006; Aerts et al., 2007; Vieira et al., 2008).

Seasonality is another major aspect of restoration activities, since the main limiting factor for seedling establishment and survival in all dry forest regions is drought (Elliott et al., 2002; Aerts et al., 2007; Maass and Burgos, 2011; Williams-
Linera et al., 2011a). Seasonality in rainfall, the start of the rainy period, variation in annual precipitation, frequent dry spells during the wet season, and high temperatures are the major limiting factors for seed germination as well as plant survival and growth over successive seasons (Gerhardt and Hytterborn, 1992; Castro et al., 2002; Ceccon et al., 2004; Vieira and Scariot, 2006; Negussie et al., 2008; Vieira et al., 2008; Griscom et al., 2009; Quesada et al., 2009; Craven et al., 2011).

In Central Veracruz, Mexico, SDTF has been reduced to $7 \%$ of its original cover; fallow periods are short, usually no longer than 7-10 years, making old secondary successional sites unavailable. Despite these short fallow periods, intense land use, and harsh environmental conditions, secondary vegetation and natural regeneration, although scarce, is present on abandoned sites (Williams-Linera et al., 2011a, b).

A successful restoration approach depends on understanding a forest's capacity to regenerate and identifying environmental factors that improve the artificial establishment of seedlings. Tree species should be carefully selected and site conditions taken into account when evaluating restoration. The working hypothesis that each species responds differently to site condition depending on its successional status may be accepted for some species. However, seedling dynamics in SDTF may be more sensitive to seasonality than successional status (Ceccon et al., 2004). The aim of this study was to identify the effect of existent vegetation on seedling performance by comparing early seedling survival and growth during the dry and wet seasons, as well as to evaluate each species' responses as possible indicators of successful performance during SDTF restoration assays.

\section{Material and methods}

Study area. The study was carried out in the SDTF region of central Veracruz, Mexico (19 ${ }^{\circ} 17^{\prime} \mathrm{N}, 9^{\circ} 6^{\circ} 26^{\prime} \mathrm{W}, 100-250$ $\mathrm{m}$ a.s.1.). Mean minimum and maximum temperatures are

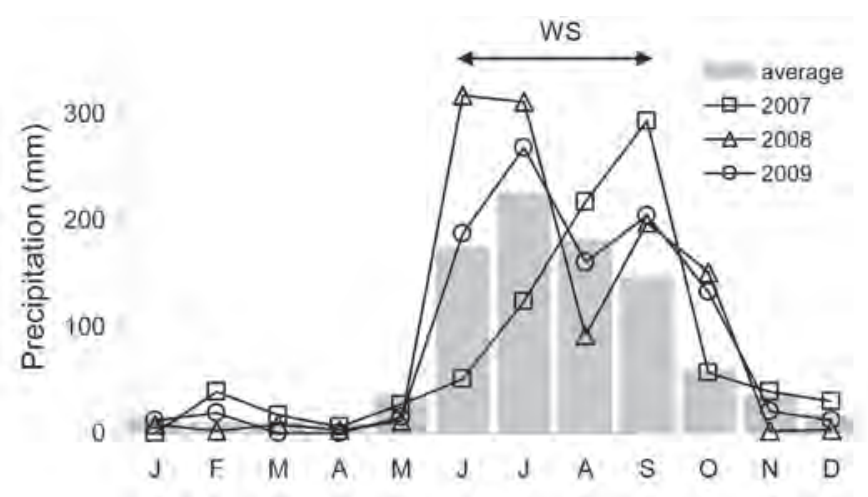

Figure 1. Monthly rainfall at the meteorological station of Loma Fina, Veracruz, Mexico, during 2007-2009. Average precipitation is the monthly mean from 1961-2006. The arrow indicates the wet season (WS) months. 
20 and $31^{\circ} \mathrm{C}$, respectively. Mean annual precipitation is 950 $\mathrm{mm}$ (range: $502-1,466 \mathrm{~mm}$ ), with $86 \%$ of the rainfall occurring between June and October (Figure 1). Meteorological records were obtained from the nearest meteorological station, which is located at Loma Fina, 9-20 km from the sites. Soils are mainly Cambisols and Vertisols with frequent exposed rock. Common canopy tree species are Bursera cinerea, B. fagaroides, B. graveolens, B. simaruba, Calyptranthes schiediana, Comocladia engleriana, Ipomoea wolcottiana, Leucaena lanceolata, Savia sessiliflora, Tabebuia chrysantha, and Thouinidium decandrum (Williams-Linera and Lorea, 2009). Detailed descriptions of forest loss, land tenure, and historical land use can be found in Newton and Tejedor (2011) and Williams-Linera et al. (2011a, b). Local population knowledge on woody species for SDTF restoration is reported in Suárez et al. (2012).

Study sites. In the study area, four abandoned sites were selected (Table 1A). Age of abandonment and history of land use -particularly fire frequency, past number of cattle, and periodicity of use for pasture or crop- were determined from interviews with local inhabitants (Williams-Linera et al., 2011b). Before the restoration experiment began, four $10 \times 10 \mathrm{~m}$ plots were established within the transplantation stand at each site (Figure 2). On each plot, we counted the number of individuals, measured their diameter at ground level, and identified woody species for all plants $\geq$ $1 \mathrm{~m}$ height. On each plot, during the rainy season of 2008 soil samples were collected to a depth of $15 \mathrm{~cm}$ for physical and chemical analyses. They were then air dried in the laboratory and passed through a $2.0 \mathrm{~mm}$ sieve. Soil texture was determined using the Bouyoucos methods; soil pH was measured in a 1:2 soil-water solution. Soil organic matter

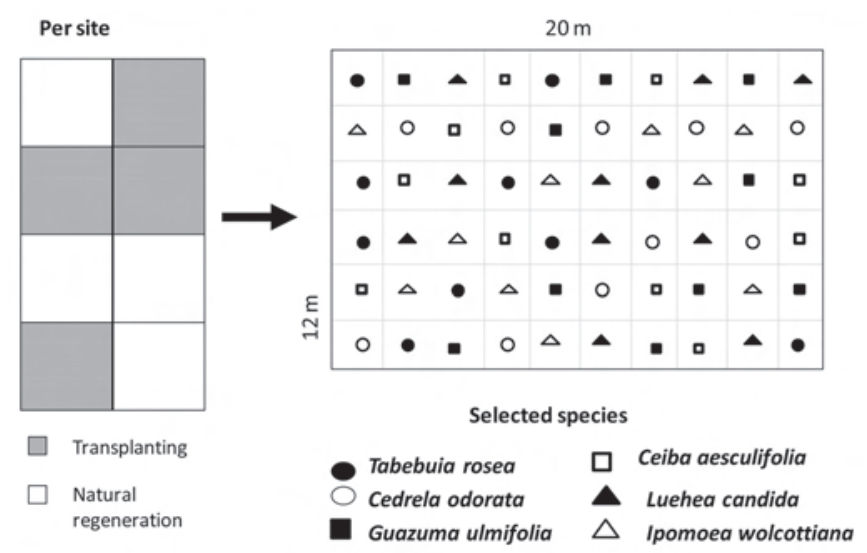

Figure 2. Experimental design established in the SDTF region of central Veracruz, Mexico. At each study site a $24 \times 80 \mathrm{~m}$ parcel was established and eight plots were randomly arranged, four to evaluate the existing natural regeneration (unshaded areas) and four to transplant 240 seedlings of six tree species (60 seedlings per plot). Selected tree species are indicated with symbols.
$(\mathrm{OM})$ was determined using the Walkley Black method, and total $\mathrm{C}$ and $\mathrm{N}$ were measured with an automatic analyzer of CN Truspec (LECO). Bulk density was determined using the clod method.

Species selected. We selected six tree species: Cedrela odorata L. (Meliaceae), Ceiba aesculifolia (Kunth) Britten \& Baker (Bombacaceae), Guazuma ulmifolia Lam. (Sterculiaceae), Ipomoea wolcottiana Rose (Convolvulaceae), Luehea candida (Moc. \& Sessé ex DC.) Mart. (Tiliaceae), and Tabebuia rosea (Bertol.) DC. (Bignoniaceae). The selected species were classified as pioneer or mature forest species after Lebrija-Trejos et al. (2010). Guazuma ulmifolia can be considered as an early successional or pioneer tree and the other species as late successional species. Hereafter, these species will be referred to by genus only. They were selected based on their abundance and socioeconomic importance. Two are timber species (Tabebuia and Cedrela), one is used as forage (Guazuma), and the other three are used for firewood, ornamental applications, and to manufacture handicrafts; one (Ipomoea) is used to grow edible mushrooms.

Seeds were collected from the study area and propagated at a local nursery (La Unidad, $15 \mathrm{~km}$ from the restoration sites). Thirty days after germination, seedlings were transplanted to small black plastic bags $(6 \times 8 \times 20 \mathrm{~cm})$ filled with a mixture of sand $(30 \%)$ and forest soil $(70 \%)$. For transplants, we used 4-6 month old seedlings. Mean seedling height and basal diameter at transplantation were 15.1 $\mathrm{cm}, 5.5 \mathrm{~mm}$ for Cedrela; $37.7 \mathrm{~cm}, 8.1 \mathrm{~mm}$ for Ceiba; 31.7 cm, $4.6 \mathrm{~mm}$ for Guazuma; $37.7 \mathrm{~cm}, 11.5 \mathrm{~mm}$ for Ipomoea; $36.9 \mathrm{~cm}, 5.4 \mathrm{~mm}$ for Luehea; and $18.5 \mathrm{~cm}, 5.5 \mathrm{~mm}$ for $T a$ bebuia, respectively.

Experimental design. The four study sites were fenced off with barbed wire to exclude livestock prior to the start of the restoration experiment. The peak of the 2007 rainy season was late: June and July featured $29 \%$ and $55 \%$, of expected precipitation, respectively. In contrast, August and September featured $121 \%$ and $202 \%$ of the expected precipitation, respectively (Figure 1); therefore, we delayed initial planting until the soil had retained enough moisture (see Maass and Burgos, 2011). During September 2007, a total of 960 seedlings were transplanted and numbered with metal tags. At each site, 60 seedlings per plot (ten of each selected species) were transplanted to four $12 \times 20 \mathrm{~m}$ plots, with individuals spaced $2 \mathrm{~m}$ apart (Figure 2). The experiment began in October 2007; plant survival and basal diameter/height were measured every 4 months until October 2009. Our intention was to repeat these measurements after a year, but in September 2010 Hurricane Karl destroyed most of the vegetation in the area. In October 2010, surviving species were recorded.

Survival was estimated as the number of individuals 
Table 1. Characteristics of the sites where the restoration parcels were established in the SDTF region of central Veracruz, Mexico. A. Site location and land use history including number were of months as fallow, use for crop or pasture for cattle, cattle categorical value $\left(^{1}\right.$ combination of frequency and number of heads), fire categorical value ( ${ }^{2}$ combination of frequency and years since last burned). B. Existent vegetation variables for woody plants $\geq 1 \mathrm{~m}$ height are basal area $\left(\mathrm{m}^{2} / \mathrm{ha}\right)$, density (individuals $\left./ \mathrm{ha}\right)$, mean and maximal height $(\mathrm{m})$, and observed tree species $\left(\mathrm{S}_{\mathrm{obs}}\right.$ in $\left.400 \mathrm{~m}^{2}\right)$. C. Soil variables are total carbon $\left(\mathrm{C}_{\text {total }}\right)$, nitrogen percent $(\mathrm{N}), \mathrm{C}: \mathrm{N}$ ratio, organic matter $(\mathrm{OM})$, organic carbon $\left(\mathrm{C}_{\text {organic }}\right), \mathrm{pH}\left(1: 1 \mathrm{H}_{2} \mathrm{O}\right)$, texture, and bulk density $\left(\mathrm{g} / \mathrm{cm}^{3}\right)$. Values are mean, with SE in parentheses. One-way ANOVAs comparing sites were significant for some variables; different letters in a row indicate significant differences between sites.

\begin{tabular}{|c|c|c|c|c|}
\hline \multirow[t]{2}{*}{ A. Site } & \multicolumn{4}{|c|}{ Locality } \\
\hline & $\begin{array}{c}1 \\
\text { Dios Tigre }\end{array}$ & $\begin{array}{c}2 \\
\text { Don Tirso }\end{array}$ & $\begin{array}{c}3 \\
\text { Los Morales }\end{array}$ & $\begin{array}{c}4 \\
\text { Rinconada }\end{array}$ \\
\hline Municipality & Paso Ovejas & Emiliano Zapata & Paso Ovejas & Emiliano Zapata \\
\hline Altitude (m) & 175 & 250 & 130 & 220 \\
\hline Latitude N & $19^{\circ} 17^{\prime} 34^{\prime \prime}$ & $19^{\circ} 21^{\prime} 59^{\prime \prime}$ & $19^{\circ} 17^{\prime}$ & $19^{\circ} 21^{\prime} 47^{\prime \prime}$ \\
\hline Longitude W & $96^{\circ} 27^{\prime} 7^{\prime \prime}$ & $96^{\circ} 32^{\prime} 45^{\prime \prime}$ & $96^{\circ} 26^{\prime}$ & $96^{\circ} 34^{\prime} 8^{\prime \prime}$ \\
\hline \multicolumn{5}{|c|}{ Land use history } \\
\hline Fallow (mo) & 72 & 36 & 7 & 8 \\
\hline Corn field & No & No & No & Yes \\
\hline Pasture & Yes & Yes & Yes & No \\
\hline Cattle $^{1}$ & 1 & 2 & 3 & 0 \\
\hline Frequency & occasional & frequent & always & never \\
\hline Heads/ha & $<10$ & $>10$ & $>50$ & - \\
\hline Fire $^{2}$ & 2 & 1 & 2 & 3 \\
\hline Frequency & frequent & occasional (10 yr) & frequent & every yr \\
\hline Last fire (yr) & 1 & 10 & 3 & 1 \\
\hline \multicolumn{5}{|c|}{ B. Existent vegetation } \\
\hline Basal area & $2.13(1.34)$ & $3.21(2.67)$ & $2.00(0.70)$ & $0.60(0.20)$ \\
\hline Individuals & $1533(312)$ & $900(379)$ & $1600(618)$ & $908(202)$ \\
\hline Height $_{\text {mean }}$ & $2.20(0.46)$ & $3.60(0.76)$ & $2.28(0.28)$ & $2.02(0.27)$ \\
\hline Height $_{\max }$ & $2.91(0.83)$ & $4.40(0.93)$ & $2.71(0.26)$ & $2.24(0.26)$ \\
\hline$\underline{\mathrm{S}_{\mathrm{obs}}}$ & $10^{\mathrm{a}}$ & $18^{\mathrm{a}}$ & $11^{\mathrm{a}}$ & $8^{\mathrm{b}}$ \\
\hline \multicolumn{5}{|l|}{ C. Soil } \\
\hline$C_{\text {total }}$ & $2.73(0.17)^{\mathrm{bc}}$ & $8.64(0.33)^{\mathrm{a}}$ & $1.80(0.16)^{c}$ & $4.42(0.18)^{b}$ \\
\hline $\mathrm{N}$ & $0.26(0.02)^{\mathrm{b}}$ & $0.95(0.03)^{\mathrm{a}}$ & $0.16(0.01)^{\mathrm{c}}$ & $0.38(0.01)^{\mathrm{b}}$ \\
\hline $\mathrm{C}: \mathrm{N}$ & $10.47(0.18)$ & $9.10(0.18)$ & $11.18(0.41)$ & $11.56(0.34)$ \\
\hline $\mathrm{OM}$ & $4.13(0.23)^{\mathrm{b}}$ & $10.46(0.53)^{\mathrm{a}}$ & $3.42(0.31)^{\mathrm{b}}$ & $5.28(0.27)^{\mathrm{b}}$ \\
\hline $\mathrm{C}_{\text {organic }}$ & $2.39(0.13)^{\mathrm{b}}$ & $6.07(0.31)^{\mathrm{a}}$ & $1.98(0.18)^{\mathrm{b}}$ & $3.06(0.16)^{b}$ \\
\hline $\mathrm{pH}$ & $6.40(0.05)^{\mathrm{b}}$ & $7.72(0.06)^{\mathrm{a}}$ & $6.49(0.05)^{\mathrm{b}}$ & $7.54(0.02)^{\mathrm{a}}$ \\
\hline Texture & Clay & Clay & Sandy-clay-loam & Clay \\
\hline Bulk density & $2.36(0.07)$ & $1.86(0.10)$ & $2.25(0.15)$ & $2.06(0.13)$ \\
\hline
\end{tabular}

alive in each survey period. Relative growth rates (RGR) of height and stem basal diameter were calculated as follows (Hunt, 1990):

$\mathrm{RGR}=\log _{\mathrm{e}} \mathrm{W}_{2}-{ }_{\text {Loge }} \mathrm{W}_{1} / \mathrm{t}_{2}-\mathrm{t}_{1}$ where $\mathrm{W}_{2}$ and $\mathrm{W}_{1}$ are final and initial growth measurements and $t_{2}-t_{1}$ was the number of months.

Data analyses. Since some of the plants survived for the duration of the study, survivorship curves were analyzed as censored survival data using the Kaplan-Meier survival platform. This analysis is a nonparametric test for comparing the distribution of life-spans within groups; Wilcoxon statistics was used to test homogeneity between groups.
RGR in height (RGRh) and basal diameter (RGRd) were averaged within a plot and estimated for two dry and two wet seasons. The first dry season was November 2007-May 2008 and the second November 2008-May 2009; the first and second wet seasons were June-October in 2008 and 2009, respectively (Figure 1). Repeated-measures ANOVAs were used to test differences among species and sites using seasons as repeated measures. Survival data were arcsin square root transformed prior to the analysis. Seedling survival, RGRh, and RGRd at month 24 as well as basal area, density, richness, and soil variables were tested using oneway ANOVAs. In all ANOVAs, we examined the residuals for normality with the Shapiro-Wilk test. We used Tukey 
HSD test to detect differences between pairs of means.

Initial height and diameter of the seedlings at the inception of the experiment were correlated with survival at 12-mo; final seedling survival, RGRh, and RGRd were correlated with site vegetation, soil, and disturbance variables with the Spearman $\rho$ correlation coefficient. Statistical analyses were carried out using the statistical package JMP version 6.0.0 (SAS Institute, Cary, North Carolina, USA).

\section{Results}

Differences among sites. The restoration sites have similar disturbance histories but differ in the intensity of land use and time since abandonment. Fire was present as an element of management dynamics at all sites. Livestock was recorded as part of the disturbance history at three sites, while one was used only to grow corn (Table 1A). Neither vegetation structure and richness for woody plants $\geq 1 \mathrm{~m}$ height nor soil variables were significantly related to the age of the fallow (Table 1B, C). There was a non-significant trend toward higher structural values at older sites. However, the number of woody species was significantly higher in older fallows (Table 1B). Sites differed significantly with respect to some soil variables. The soil $\mathrm{pH}$ was slightly basic at sites 2 and 4 and slightly acidic at sites 1 and 3 . Site 2 had the best soil conditions, with the highest percentages of organic matter, organic $\mathrm{C}$, and total $\mathrm{C}$ and $\mathrm{N}$ (Table $1 \mathrm{C}$ ).

Sites 1 and 3 (Figure 3A, C) were considered intermediate in vegetation structure, species richness, and intensity of soil use. Site 2 (Figure 3B) was taken to have good site conditions due to its highest basal area, vegetation height, and species richness, as well as better soil characteristics than the others. Site 4 (Figure 3D) had the lowest vegetation structure and number of woody species.
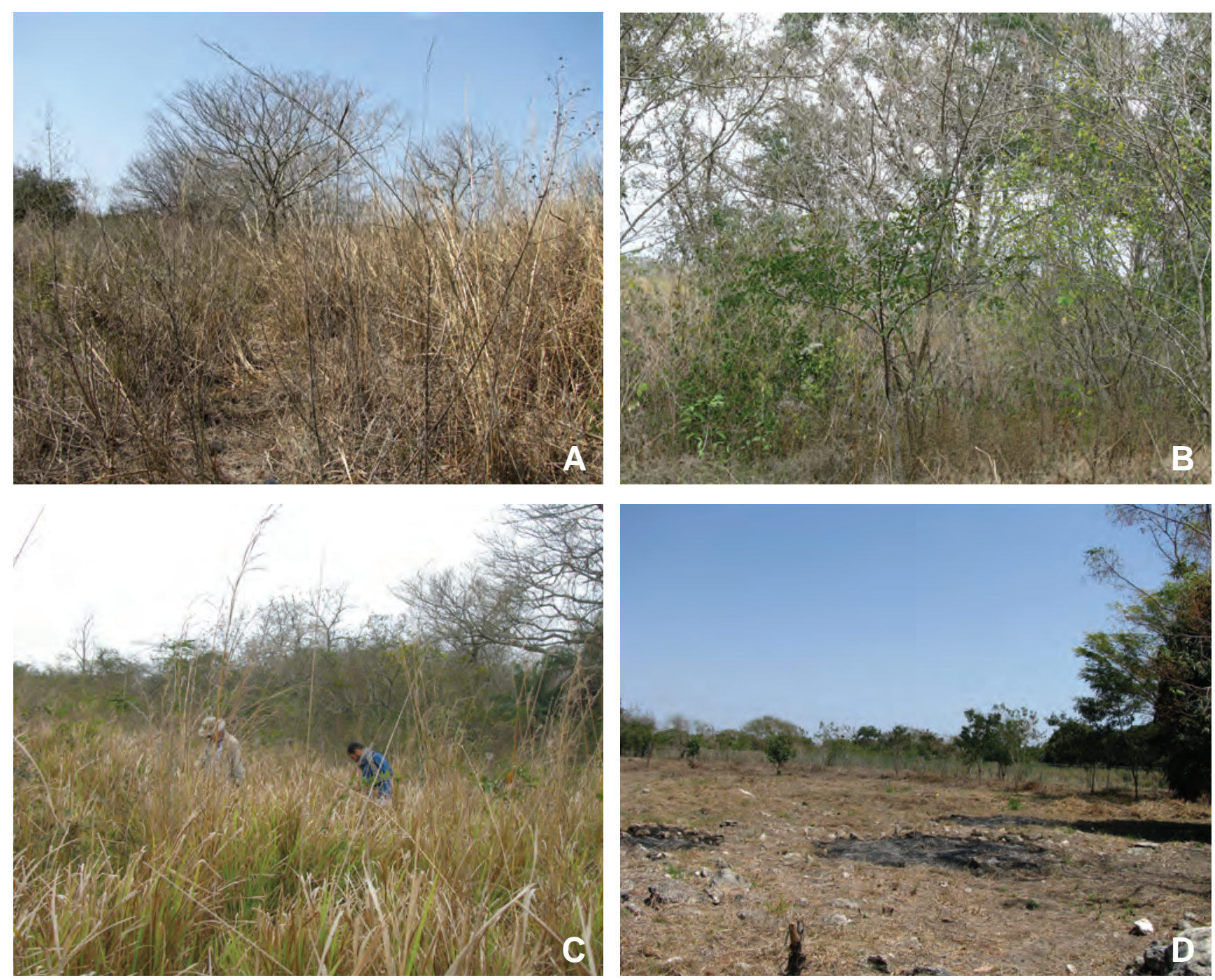

Figure 3. Photographs of the study sites in the SDTF region of central Veracruz, Mexico, taken during the 2007 dry season before the restoration assays were begun. A. Site 1 is Dios Tigre, B. Site 2 is Don Tirso, C. Site 3 is Los Morales, D. Site 4 is Rinconada. 
Table 2. Repeated measures ANOVA for relative growth rate in height RGRh) and diameter (RGRd) of six tree species in each site during two dry and two wet seasons in the SDTF region of central Veracruz, Mexico. Seedlings that lost stems were not used for RGR analyzes although they were alive.

\begin{tabular}{|c|c|c|c|c|c|}
\hline \multirow[b]{2}{*}{ Source } & \multicolumn{3}{|c|}{ RGRh } & \multicolumn{2}{|c|}{ RGRd } \\
\hline & $\mathrm{df}$ & $F$ & $P$ & $F$ & $P$ \\
\hline \multicolumn{6}{|l|}{ Site 1} \\
\hline Species & 4,64 & 14.36 & $<0.0001$ & 2.82 & 0.03 \\
\hline Species $x$ Season & 4,64 & 17.77 & $<0.0001$ & 2.69 & 0.04 \\
\hline \multicolumn{6}{|l|}{ Site 2} \\
\hline Species & 5,79 & 11.22 & $<0.0001$ & 6.11 & $<0.0001$ \\
\hline Species $\times$ Season & 5,79 & 25.04 & $<0.0001$ & 7.86 & $<0.0001$ \\
\hline \multicolumn{6}{|l|}{ Site 3} \\
\hline Species & 4,68 & 14.03 & $<0.0001$ & 5.30 & $<0.001$ \\
\hline Species $\times$ Season & 4,68 & 12.05 & $<0.0001$ & 9.25 & $<0.0001$ \\
\hline \multicolumn{6}{|l|}{ Site 4} \\
\hline Species & 5,58 & 15.26 & $<0.0001$ & 6.94 & $<0.0001$ \\
\hline Species $\times$ Season & 5,58 & 12.38 & $<0.0001$ & 4.65 & $<0.01$ \\
\hline
\end{tabular}

Seedling survival. Survivorship curves were statistically different among restoration sites $\left(\chi^{2}=39, \mathrm{df}=3, P<0.0001\right)$ and species $\left(\chi^{2}=128\right.$, df $\left.=5, P<0.0001\right)$. At sites 1 and 3 , they were statistically similar; however, the survivorship curves of all other sites differed, with site 2 displaying the highest and site 4 the lowest. Species responded differently to site condition. Ceiba and Guazuma displayed the highest survivorship curves at all sites (Figure 4). At sites 1 and 2,

Table 3. Spearman correlation coefficients between seedling survival at two years, relative growth rate in height (RGRh), and diameter (RGRd) during the restoration experiment, and site characteristics of the restoration sites. Variables for vegetation $\geq 1 \mathrm{~m}$ tall are basal area, density, mean and maximal height, and richness. Soil variables are carbon, nitrogen \%, organic matter \%, pH, C: $\mathrm{N}$ ratio, organic carbon, and bulk density.

\begin{tabular}{lcccccc}
\hline & \multicolumn{2}{c}{ Survival } & \multicolumn{2}{c}{ RGRh } & \multicolumn{2}{c}{ RGRd } \\
& $\rho$ & $\mathrm{P}$ & $\rho$ & $\mathrm{P}$ & $\rho$ & $\mathrm{P}$ \\
\hline Vegetation & & & & & & \\
Basal area & 0.05 & 0.85 & 0.23 & 0.40 & 0.03 & 0.92 \\
Density & -0.08 & 0.76 & 0.18 & 0.51 & -0.05 & 0.85 \\
Height $_{\text {mean }}$ & 0.33 & 0.22 & 0.53 & $\mathbf{0 . 0 4}$ & 0.23 & 0.40 \\
Height $_{\text {maximal }}$ & 0.35 & 0.18 & 0.53 & $\mathbf{0 . 0 3}$ & 0.29 & 0.28 \\
Richness & 0.57 & $\mathbf{0 . 0 2}$ & 0.68 & $\mathbf{0 . 0 0}$ & 0.38 & 0.15 \\
& & & & & & \\
Soil & & & & & & \\
Carbon & 0.23 & 0.39 & 0.27 & 0.32 & 0.55 & $\mathbf{0 . 0 3}$ \\
Nitrogen & 0.24 & 0.37 & 0.28 & 0.29 & 0.55 & $\mathbf{0 . 0 3}$ \\
Organic matter & 0.35 & 0.18 & 0.43 & 0.10 & 0.55 & $\mathbf{0 . 0 3}$ \\
pH & 0.18 & 0.51 & 0.12 & 0.66 & 0.50 & $\mathbf{0 . 0 5}$ \\
C:N & -0.57 & $\mathbf{0 . 0 2}$ & -0.47 & $\mathbf{0 . 0 6}$ & -0.02 & 0.93 \\
Organic C & 0.35 & 0.18 & 0.43 & 0.10 & 0.55 & $\mathbf{0 . 0 3}$ \\
Bulk density & -0.23 & 0.38 & -0.23 & 0.39 & -0.53 & $\mathbf{0 . 0 3}$ \\
\hline
\end{tabular}

Ipomoea and Luehea displayed intermediate and similar survivorship curves, while Tabebuia and Cedrela displayed the lowest curves throughout the restoration experiment (Figure 4A, B). At site 3, Ipomoea and Cedrela displayed the lowest curves (Figure 4C). At site 4, all species displayed the lowest survivorship curves (Figure 4D).

At the end of the two-year experiment, seedling survival was statistically different among sites $(\mathrm{F}=107$, df $=3,72$, $P<0.0001)$, species $(\mathrm{F}=50.5$, df $=5,72, P<0.0001)$, and the interaction between the two $(\mathrm{F}=15.0$, df $=15,72, P<$ 0.0001). Seedling survival was higher at sites 2 and 3 (60 and $49 \%$, respectively), intermediate at site 1 (29\%), and very low at site 4 (2\%). Cedrela displayed the lowest plant survival and disappeared at sites 1 and 4; Guazuma survived at all four study sites, and Ceiba performed the best at sites 1,2 , and 3 .

Seedling growth. After 24 months, seedlings at sites 2 and 3 showed a higher RGRh $(\mathrm{F}=8.77, \mathrm{df}=3,56, P<0.0001)$ and RGRd ( $\mathrm{F}=5.13$, df $=3,56, P=0.003)$ than at the other sites. RGRh $(\mathrm{F}=2.51, \mathrm{df}=5,54, P=0.04)$ and $\mathrm{RGRd}(\mathrm{F}=$ 5.24, df $=5,54, P=0.0005$ ) differed among species, with Cedrela displaying a significantly higher growth rate than Ceiba and Luehea.

At each study site, RGRh and RGRd were lower in the dry season for all species (Table 2, Figure 5). During the rainy season, Guazuma and Cedrela displayed a high RGRh and RGRd at all study sites (Figure 5A-D). Additionally, Ipomoea showed a high RGR at the site with the most vegetation (Figure 5B) and, unexpectedly, at the site with the least vegetation (Figure 5D).

Relationships. All species showed a nonsignificant correla- 

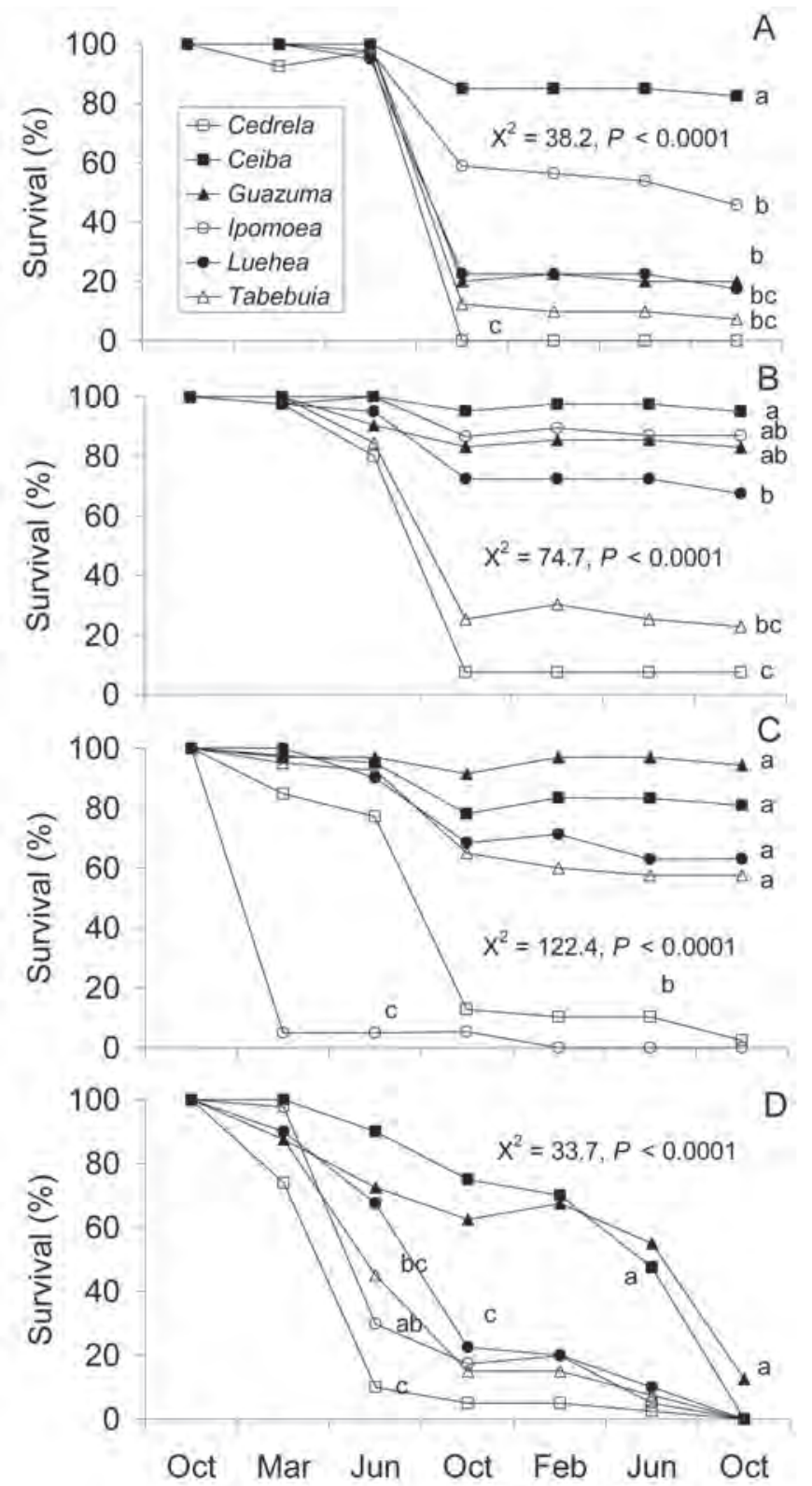

Figure 4. Survival curves of the six selected tree species throughout the study period in the SDTF region of central Veracruz, Mexico. A. Site 1, B. Site 2, C. Site 3, D. Site 4. Different letters indicate significant differences among survivorship curves of the species at each site.

tion between initial height or diameter with survival at 12 months. However, initial height and diameter of seedlings and survival were positively and significantly correlated for the site with the most vegetation (site $2, \rho=0.65,0.66$, respectively, $P<0.001$ ), and for height and survival at site 1 $(\rho=0.63, P<0.001)$. Survival and RGRh were positively correlated between themselves $(\rho=0.74, P=0.001)$ and with the woody plant richness of existent vegetation at the restoration sites, but negatively correlated with C:N. RGRh was positively correlated with the mean and maximum height of existent vegetation. In contrast, RGRd was positively correlated with several soil variables $(\mathrm{C}, \mathrm{N}, \mathrm{OM}, \mathrm{pH}$, and organic $\mathrm{C}$ ) and negatively correlated with bulk density (Table 3).

\section{Discussion}

Differences between sites in this SDTF landscape in central Veracruz are clearly the result of land use history. Our results strongly suggest that restoration success is related to site quality conditions, since the best seedling survival and RGR were recorded at sites with the highest existent woody vegetation and the greatest species richness, as well as the best soil conditions. Other results have indicated that the presence of trees and nearby forest fragments encourages ecological restoration in the dry forest regions of India (Davidar et al., 2007), Ethiopia (Aerts et al., 2007; Girma et al., 2010), Costa Rica (Janzen, 1988), Panama (Griscom et al., 2009), Puerto Rico (Santiago-García et al., 2008), and Brazil (Sampaio et al., 2007). Aerts et al. (2007) reported that the combined effect of shade and moisture conservation under pioneer shrub cover enhances the survival of planted seedlings compared to seedlings planted in bare soil patches; therefore, planting under shrubs may contribute to the regeneration of dry Afromontane vegetation in Ethiopia. In addition, Davidar et al. (2007) reported that in India, sites with lower tree densities have increased light and temperature levels in the understory, causing higher seedling mortality due to desiccation. Apparently, nurse plants provide a suitable microenvironment that promotes the survival and growth of planted trees -protecting them against high irradiance and temperatures, improving water status, and increasing nutrients because of accumulation of litterfall, as well as reducing the risk of fire by decreasing the amount of grass cover around planted trees (Castro et al., 2002; Vieira and Scariot, 2006; Davidar et al., 2007; Santiago-García et al., 2008).

Our results suggest that areas previously used for line crops are less responsive to restoration efforts than pastures with isolated woody individuals. We found that pastures being less intensively managed may recover faster than the annual crop field. Similarly, other authors have found that the presence of woody plant canopies control seedling desiccation during the dry season; seed germination and early seedling survival improve below canopy because soil retains moisture longer and microclimate is milder than in open areas. However, in open areas seedling growth is higher than in shaded ones (Vieira et al., 2006, 2008). Existent vegetation and tree species richness, even at sites that have suffered disturbance for many years, have the potential to accelerate succession and permit original forest recovery (Sampaio $e t$ al., 2007; Williams-Linera et al., 2011b).

Seedling survival was similar during wet and dry seasons at the sites with the best soil conditions and the most 


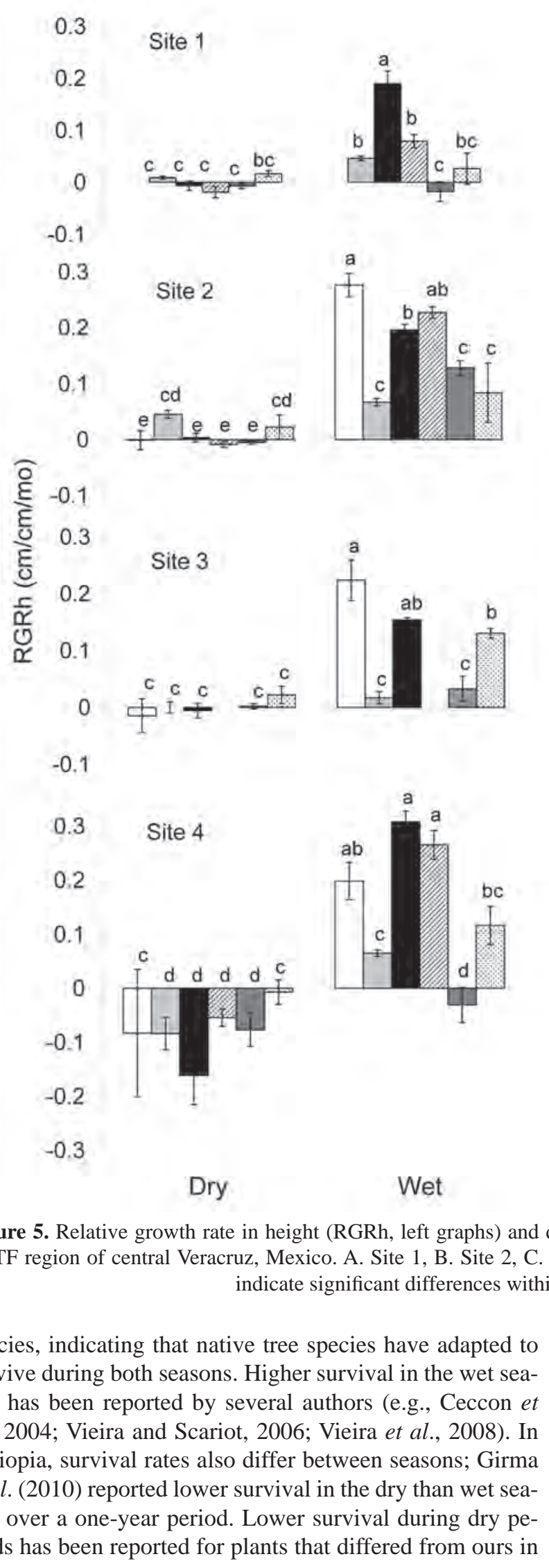

\subsection{5}

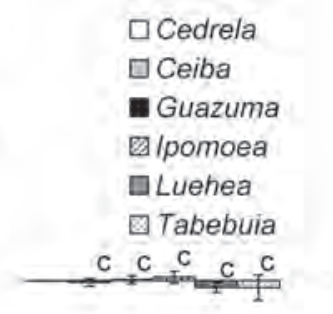

$-0.05$

0.25

0.15

0.05

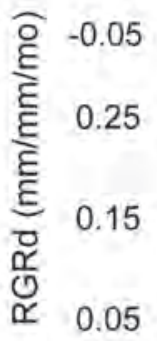

$-0.05$

0.25

0.15

0.05

$-0.05$
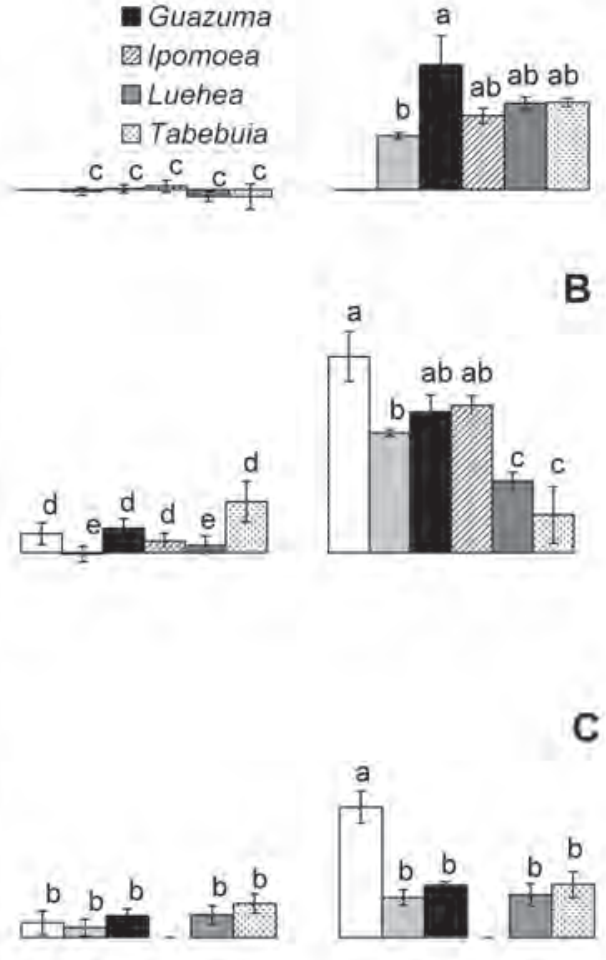

B

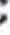
年 
moted some degree of drought tolerance.

All species displayed an abrupt decrease in survival by the end of the first year, while survival did not decrease much during the following seasons. Apparently, seedlings surviving the first year have passed an establishment filter. Furthermore, lower survival in the first wet season may relate to high insect herbivory, since in the nearby forest we observed complete defoliation of some tree species (GWL et al., unpublished). Vieira et al. (2008) reported that high mortality at the onset of the rainy season probably resulted from seedlings' inability to sprout once the rain started, due to stress suffered during the dry season.

Seedling growth in height and diameter was related to both seasonality and site condition. The wet season facilitated the growth of all species at all sites. During the dry season, seedlings at site 4 with meager existent vegetation displayed the lowest RGR, since seasonal drought stress limits plant growth (Craven et al., 2011; Maass and Burgos, 2011). High light intensity increases seedling growth, but in a dry region it is related to low survival due to desiccation (Vieira and Scariot, 2006; Vieira et al., 2008; Girma et al., 2010).

Fast growth, seasonal drought tolerance, fire resistance, sprouting, and successional status are some species attributes that are important during the ecological restoration of a dry habitat (Vieira and Scariot, 2006; Santiago-García et al., 2008; Craven et al., 2011). In addition, in Veracruz, some of the selected species have been reported as useful by local people; in particular, Cedrela, Guazuma, and Tabebuia were favorites for forest restoration based on local knowledge (Suárez et al., 2012). The working hypothesis that each species responds differently to site conditions depending on its successional status may be accepted for some species. The selected tree species displayed some of the attributes mentioned, but not all of them exhibited a successful seedling performance during the restoration process. Cedrela displayed the poorest survival and probably is the least drought adapted of the selected species; for this reason, the use of Cedrela is recommended only if water and partial shade are available (Suárez-Islas, 2011). In contrast, Cedrela displayed a high RGR and is one of the most valuable timber species, being used widely on local plantations (Suárez et al., 2012). Guazuma, an early successional or pioneer tree, was the species with the best seedling performance at all sites. This species exhibits a great adaptive capacity in terms of the physiological adjustment of traits (net photosynthesis, transpiration, growth rate) in response to changes in light and water availability in different seasons (Craven et al., 2011). These adaptations explain the species' ability to colonize open areas, becoming the most common species in early succession (Griscom et al., 2009; Williams-Linera et al., 2011b). Tabebuia displayed low survival and RGR. In Nicaragua, Castro-Marín et al. (2011) reported that Tabebuia has the highest survival at an open site, with the development of spreading crowns that rapidly shade out herba- ceous plants; the authors therefore suggest that it serves as a framework species for the restoration of degraded and/or abandoned sites. The other species have certain characteristics that should be considered. Ceiba and Luehea were not popular among local people for use in restoration, but Ceiba showed the best survival both in the wet and dry seasons, indicating that it is drought tolerant. Luehea showed low survival and growth rates; however, Craven et al. (2011) reported high water-use efficiency in another species of the same genus. Ipomoea seedlings performed well during the wet season both in terms of survival and RGR, and it is a useful tree that locals could employ in restoration efforts (Suárez et al., 2012).

In September 2010, central Veracruz suffered a major hurricane, impacting the study region. After Hurricane Karl, we did a survival count and found that seedlings had managed to survive at the less disturbed sites (sites 1 and 2). At site 4, however, no seedlings survived. Furthermore, during the dry season of 2011, fires burned out of control, completely obliterating the restoration assay at site 3 .

\section{Conclusions}

This study shows that site quality conditions, particularly in the height and richness of existent vegetation, are as important as tree species selection in ecological restoration activities. Restoration is clearly influenced by site condition, since the better sites displayed higher seedling survival and growth. Seedlings of different species may behave differently in response to seasonality, indicating a level of drought tolerance that merits further exploration. The restoration assay was evaluated for only 24 months, but it is vital to monitor the experiments for several years to ensure prudent decision making and the expansion of knowledge on dry forest recovery. When Hurricane Karl struck our study region, we monitored the experimental plantations for a few more months and observed that plants were able to recover. Our short study showed how important it is to take advantage of existing natural vegetation to ensure the success of seedling transplantion; it also demonstrated the resilience of native tree species in the face of environmental factors during restoration activities.

\section{Acknowledgments}

We are grateful to Javier Tolome and to Marichu Peralta for valuable help and friendship. D.L.M. Vieira and an anonymous referee provided valuable suggestions on how to improve this paper. We thank the landowners who permitted fieldwork on their properties: Don Tirso and "Centro de Atención Múltiple" in Rinconada as well as Miguel Morales and Rene Blásquez in Paso de Ovejas. This research was funded by the European Community under INCO Project ReForLan CT2006-032132. 


\section{Literature cited}

Aerts R., Negussie A., Maes W., November E., Hermy M. and Muys B. 2007. Restoration of dry Afromontane forest using pioneer shrubs as nurse-plants for Olea europaea ssp. cuspidate. Restoration Ecology 15:129-138.

Castro J., Zamora R., Hódar J.A. and Gómez J.M. 2002. Use of shrubs as nurse plants: a new technique for reforestation in Mediterranean mountains. Restoration Ecology 10:297-305.

Castro-Marín G., Tigabu M., González-Rivas B. and Odén P.C. 2011. Germination requirements and seedling establishment of four dry forest species from Nicaragua. Tropical Ecology 52:1-11.

Ceccon E., Huante P. and Rincón E. 2006. Abiotic factors influencing tropical dry forests regeneration. Brazilian Archives of Biology and Technology 49:305-312.

Ceccon E., Sánchez S. and Campo J. 2004. Tree seedling dynamics in two abandoned tropical dry forests of differing successional status in Yucatán, Mexico: a field experiment with $\mathrm{N}$ and $\mathrm{P}$ fertilization. Plant Ecology 170:277-285.

Craven D., Dent D., Braden D., Ashton M.S., Berlyna G.P. and Hall J.S. 2011. Seasonal variability of photosynthetic characteristics influences growth of eight tropical tree species at two sites with contrasting precipitation in Panama. Forest Ecology and Management 261:1643-1653.

Davidar P., Nayak K.G. and Dharmalingam M. 2007. Effect of adult density on regeneration success of woody plants in natural and restored tropical dry evergreen forest fragments in Puducherry region, India. Current Science 92:805-811.

Dirzo R., Young H.S., Mooney H.A. and Ceballos G. 2011. Seasonally Dry Tropical Forest: Ecology and Conservation. Island Press, Washington, DC.

Elliott S., Kuarak C., Navakitbumrung P., Zangkum S., Anusarnsunthorn V. and Blakesley D. 2002. Propagating framework trees to restore seasonally dry tropical forest in northern Thailand. New Forests 23:63-70.

Gerhardt K. 1993. Tree seedling development in tropical dry abandoned pasture and secondary forest in Costa Rica. Journal of Vegetation Science 4:95-102.

Gerhardt K. and Hytterborn H. 1992. Natural dynamics and regeneration methods in tropical dry forest -an introduction. Journal of Vegetation Science 3:361-364.

Girma A., Mosandl R., El Kateb H. and Masresha F. 2010. Restoration of degraded secondary forest with native species: a case study in the highland of Ethiopia. Scandinavian Journal of Forest Research 25(S8):86-91.

Griscom H.P., Griscom B.W. and Ashton M.S. 2009. Forest regeneration from pasture in the dry tropics of Panama: effects of cattle, exotic grass, and forested riparia. Restoration Ecology 17:117-126.

Holl K.D. 2002. Effect of shrubs on tree seedling establishment in an abandoned tropical pasture. Journal of Ecology 90:179-187.

Holl K.D. and Aide T.M. 2011. When and where to actively restore ecosystems. Forest Ecology and Management 261:1558-1563.

Hunt R. 1990. Basic Growth Analysis: Plant Growth Analysis for Beginners. Unwin Hyman Ltd., London.

Janzen D.H. 1988. Management of habitat fragments in a tropical dry forest: growth. Annals of the Missouri Botanical Garden 75:105-116.

Lamb D. and Gilmour D. 2003. Rehabilitation and Restoration of Degraded Forests. International Union for Conservation of Na-
ture/World Wildlife Fund, Gland.

Lebrija-Trejos E., Meave J.A., Poorter L., Pérez-García E.A. and Bongers F. 2010. Pathways, mechanisms and predictability of vegetation change during tropical dry forest succession. Perspectives in Plant Ecology, Evolution and Systematics 12:267-275.

Maass M. and Burgos A. 2011. Water dynamics at the ecosystem level in seasonally dry tropical forests. In: Dirzo R., Young H.S., Mooney H.A. and Ceballos G. Eds. Seasonally Dry Tropical Forest: Ecology and Conservation, pp. 141-156, Island Press, Washington, DC.

Negussie A., Aerts R., Gebrehiwot K. and Muys B. 2008. Seedling mortality causes recruitment limitation of Boswellia papyrifera in northern Ethiopia. Journal of Arid Environments 72:378-383.

Newton A.C. and Tejedor N. Eds. 2011. Principles and Practice of Forest Landscape Restoration: Case Studies from the Drylands of Latin America. International Union for Conservation of Nature, Gland.

Powers J.S., Becknell J.M., Irving J., and Pérez-Aviles D. 2009. Diversity and structure of regenerating tropical dry forests in Costa Rica: geographic patterns and environmental drivers. Forest Ecology and Management 258:959-970.

Quesada M., Sanchez-Azofeifa G.A., Alvarez-Añorve M., Stoner K.E., Avila-Cabadilla L., Calvo-Alvarado J., Castillo A., Espírito-Santo M.M., Fagundes M., Fernández G.W., Gamon J., Lopezaraiza-Mikel M., Lawrence D., Cerdeira-Morellato L.P., Powers J.S., Neves F. de S., Rosas-Guerrero V., Sayago R. and Sanchez-Montoya G. 2009. Succession and management of tropical dry forest in the Americas: Review and new perspective. Forest Ecology and Management 258:1014-1024.

Rico-Gray V. and García-Franco J.G. 1992. Vegetation and soil seed bank of successional stages in tropical lowland deciduous forest. Journal of Vegetation Science 3:617-624.

Sampaio A.B., Holl K.D. and Scariot A. 2007. Does restoration enhance regeneration of seasonal deciduous forests in pastures in central Brazil? Restoration Ecology 15:462-471.

Santiago-García R.J., Molina-Colón S., Sollins P. and van Bloem S.J. 2008. The role of nurse trees in mitigating fire effects on tropical dry forest restoration: a case study. AMBIO: A Journal of the Human Environment 37:604-608.

Suárez A., Williams-Linera G., Trejo C., Valdez-Hernández J.I., Cetina-Alcalá V.M. and Vibrans H. 2012. Local knowledge helps select species for forest restoration in a tropical dry forest of central Veracruz, Mexico. Agroforestry Systems 85:35-55.

Suárez-Islas A. 2011. Identificación de especies leñosas nativas promisorias para la restauración de la selva baja caducifolia del centro de Veracruz. Ph.D. Dissertation. Colegio de Postgraduados Campus Montecilllo, Texcoco. 77 pp.

Vieira D.L.M. and Scariot A. 2006. Principles of natural regeneration of tropical dry forests for restoration. Restoration Ecology 14:11-20.

Vieira D.L.M., de Lima V.V., Sevilha A.C. and Scariot A. 2008. Consequences of dry-season seed dispersal on seedling establishment of dry forest trees: Should we store seeds until the rains? Forest Ecology and Management 256:471-481.

Vieira D.L.M., Scariot A. and Holl K.D. 2006. Effects of habitat, cattle grazing and selective logging on seedling survival and growth in dry forests of Central Brazil. Biotropica 39:269-274. 
Williams-Linera G. and Lorea F. 2009. Tree species diversity driven by environmental and anthropogenic factors in tropical dry forest fragments of central Veracruz, Mexico. Biodiversity and Conservation 18:3269-3293.

Williams-Linera G., Alvarez-Aquino C., Suárez A., Blundo C., Smith-Ramirez C., Echeverría C., Cruz-Cruz E., Bolados G., Armesto J.J., Heinemann K., Malizia L., Becerra P., Del Castillo R.F. and Urrutia R. 2011a. Experimental analysis of dryland forest restoration techniques. In: Newton A.C. and Tejedor N. Eds. Principles and Practice of Forest Landscape Restoration. Case studies from the Drylands of Latin America, pp. 131-182, International Union for Conservation of Nature, Gland.

Williams-Linera G., Alvarez-Aquino C., Hernández-Ascención E. and Toledo M. 2011b. Early successional sites and the recovery of vegetation structure and tree species of the tropical dry forest in Veracruz, Mexico. New Forests 42:131-148.

Received: September 22, 2011

Accepted: January 26, 2012 